\title{
EVALUATION OF LAND CAPABILITY FOR AGROFORESTRY DEVELOPMENT IN CILIWUNG WATERSHED
}

\author{
Rini Fitri ${ }^{1 *}$, Nuraida ${ }^{2}$, dan Eka Rahmi ${ }^{3}$ \\ ${ }^{1}$ Department of Agrotechnology, Faculty of Agriculture \\ ${ }^{2}$ Department of Agroindustrial Technology, Faculty of Agriculture \\ ${ }^{3}$ Department of Forestry, Faculty of Agriculture \\ Almuslim University, \\ Jl. Almuslim Bireuen 24263, Aceh Indonesia \\ *Email: rinnie_fitrie@yahoo.co.id
}

\begin{abstract}
Land conversion is one cause of damage to watersheds (DAS), leading to a complex problem physically, economically and socially in the upper and lower watershed. Upper Ciliwung watershed is classified as watershed of which its carrying capacity is restored as it has indicator qualification of high until very high and it is important to be handled. This research was conducted in upper Ciliwung watershed from January to February 2019. This study was aimed to analyze the cability of upper Ciliwung watershed area for the development of sustainable agroforestry. The units of land use (SPL) used for intensive observation were as many as 60 units of land use spread over seven (7) sub-watershed, namely sub-watershed of Cibalok, Cisuren, Ciliwung, Ciesek, Cisukabirus, Cisarua and Ciseseupan. The unit of land use of which its land capability class was analyzed included the use of shrub land, open land and dry land agriculture. The unit of land use will be used as a recommendation for the use of agroforestry in upper Ciliwung watershed. The results showed that the land capability class in the upper Ciliwung watershed consisted of land capability class II, covering an area of 329.7 ha (23.92\%), capability class III of 464.8 ha (33.72\%) and capability class IV of 584 ha (42.36\%). Land use of upper Ciliwung watershed was dominated by class III with dominant obstacle factor namely bumpy slope. Analysis of land capability on shrubland, open land, and dry land agriculture which spread over the unit of land use in the area of upper Ciliwung watershed was generally recommended for land use of agroforestry-agrisilvopasture and agroforestry-agrisilviculture.
\end{abstract}

Keywords: Land capability, land use, agroforestry, upper Ciliwung Watershed

\section{INTRODUCTION}

Watersheds (DAS) is an overlay of dynamic ecosystem area bounded by limiting topography which receives and collects rainwater and later discharges it through tributaries (sub-watersheds) and through a single point to the outlet. Land conversion is one cause of damage to watersheds (DAS), leading to a complex problem physically, economically and socially in both upstream and downstream area. Watershed degradation is caused by the conversion of forest land into residential, farming/agriculture mainly agricultural 
practices which do not implement soil and water conservation techniques (Sinukaban, 2007). The pace of development which is driven by increasing population growth has an impact on increasing the level of requirement of land so that conversion of land occurs, resulting in damage to the watershed ecosystem (Surni et al, 2015). Land and forest degradation pattern that occurs in watershed areas is very diverse including a decrease in vegetation density, changes in vegetation types of land cover, change of cultivated land into residential land with its watertight surface characteristic and conversion of forest lands into nonforest lands (Harjianto et al, 2016). Upper Ciliwung watershed which is located in two regencies namely Bogor Regency and Bogor City, West Java Province has an area of 15,101 ha. This region serves as a buffer area of Ciliwung watershed if changes in the components of the watershed occurs which will affect all parts of the watershed that connects upstream and downstream area.

Upper Ciliwung watershed is classified as watershed of which its carrying capacity is restored since it has indicator qualification of high until very high and it is important to be handled based on Government Regulation No. 37 Article 12, paragraph 12). Upper Ciliwung watershed located in two provinces namely West Java and Jakarta is one of 13 watersheds in extremely critical condition due to changes in land use (Pawitan H, 2004). This watershed requires watershed management efforts and careful land use for agroforestry development in order to realize sustainable watershed conditions. Agroforestry is a farming system and a land-use technology that can reduce erosion, degradation, and utilization of marginal land. In addition, soil and plants of agroforestry systems are large enough to be carbon storage in terrestrial ecosystem and play an important role in the global carbon cycle (Marwah 2009). In order to realize sustainable agroforestry development, evaluation of land capability which sets the pattern of land use in accordance with its carrying capacity is required (Yalew and Yilak, 2014). Classification of land capability is an attempt to evaluate the land for a specific use, while evaluation of land capability is land assessment (components of land) in systematic classification into several categories based on potential and barrier properties to its sustainable use (Sitorus, 2010). This study aimed to analyze the capability of upper Ciliwung watershed area for the development of sustainable agroforestry.

\section{MATERIAL AND METHODS}

Upper Ciliwung Watersheds (DAS) is administratively located in Bogor Regency and Bogor City, West Java Province. This watershed is geographically located at $6^{\circ} 37^{\prime}-6^{\circ} 46^{\prime}$ $\mathrm{S}$ and $106^{\circ} 50^{\prime}-107^{\circ} 0^{\prime} \mathrm{N}$. This study was conducted from July to December 2016. Map of unit of land use in upper Ciliwung watershed is presented in Figure 1.

Materials used in this study were soil maps, land use maps, topographic maps, rainfall data (10 past years), samples of soil and chemicals for soil analysis in the laboratory. Tools used included a set of survey equipment such as map of work, Geographical Position System (GPS), Abley level or clinometer, knife, tape measure, compass, drill ground, ring samples, plastic bags, camera and paper label for the purpose of land numbering. 


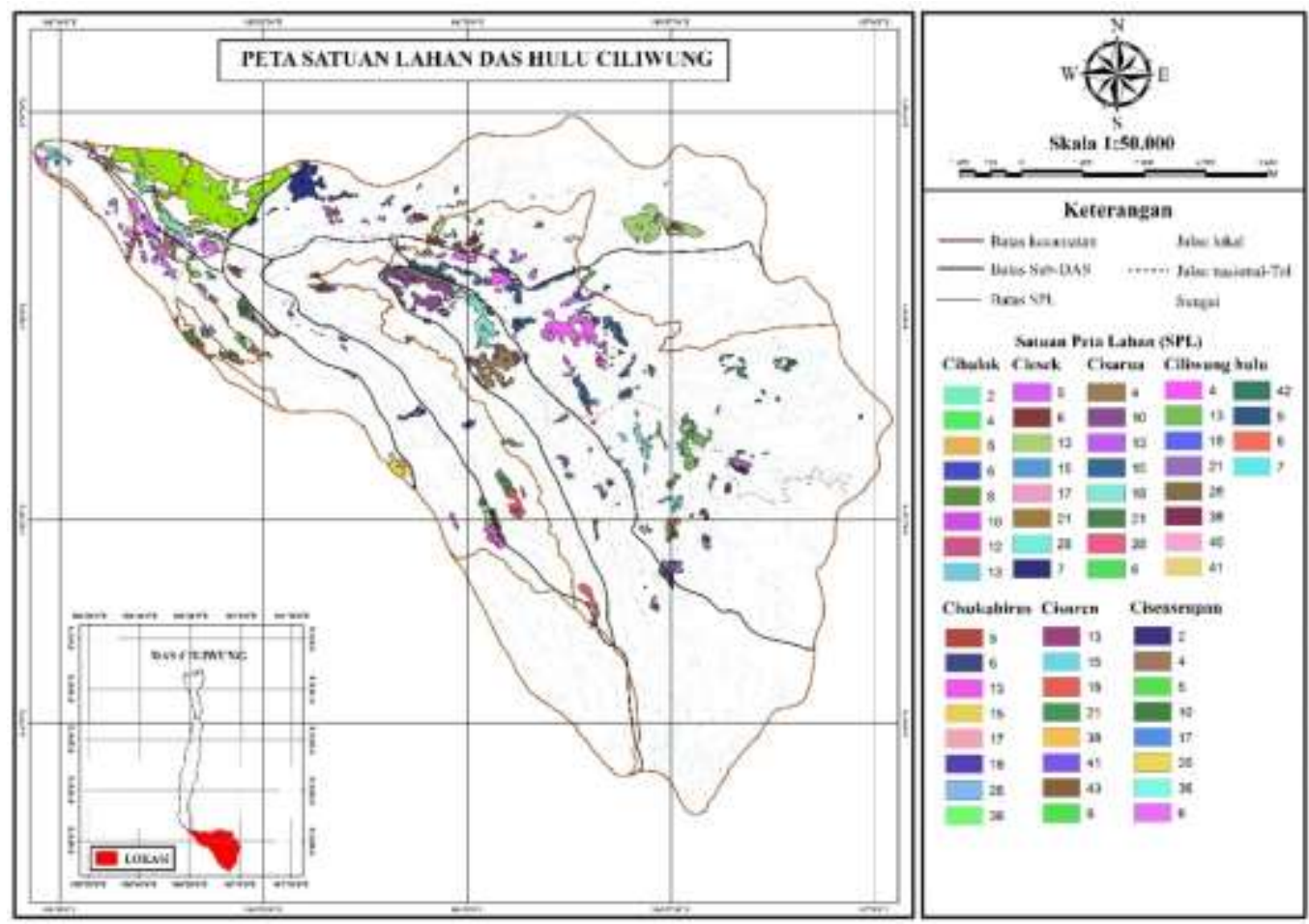

Figure 1. Map of unit of land use in upper Ciliwung watershed

Data collection technique used in this study was a survey method including the preparation of thematic maps. In the stages of preparation, activities of land use determination unit (SPL) which was the result of overlapping of slope maps, soil maps, and land use maps, were conducted. The field survey was carried out to take soil samples on each unit of land use. Soil sampling was performed on each unit of land use as much as 1 (one) point which was deliberately determined with consideration of soil characteristics in each unit of land use was the same.

Data analysis of class assessment of land capability on each unit of land use in the area of research was done using USDA land capability classification criteria. USDA classification i.e. assessment of each unit of land use was based on the physical and environmental properties as well as the type of obstacle. Land capability classification criteria are presented in Table 1.

Table 1. Land capability classification criteria

\begin{tabular}{|c|c|c|c|c|c|c|c|c|}
\hline \multirow{2}{*}{ Factor } & \multicolumn{8}{|c|}{ Land Capability Class } \\
\hline & I & II & III & IV & $\mathrm{V}$ & $\mathrm{VI}$ & VII & VIII \\
\hline \multicolumn{9}{|l|}{ 1. Soil texture $(\mathrm{t})$} \\
\hline a. Upper layer $(40 \mathrm{~cm})$ & $\mathrm{t}_{2} / \mathrm{t}_{3}$ & $\mathrm{t}_{1} / \mathrm{t}_{4}$ & $\mathrm{t}_{1}, \mathrm{t}_{4}$ & $(*)$ & $(*)$ & $(*)$ & $(*)$ & $t_{5}$ \\
\hline b. Bottom layer & $\mathrm{t}_{2 / \mathrm{t}_{4}}$ & $\mathrm{t}_{1 / \mathrm{t}_{4}}$ & $\mathrm{t}_{1 / \mathrm{t}_{4}}$ & $(*)$ & $(*)$ & $(*)$ & $(*)$ & $t_{5}$ \\
\hline 2. Surface slope (\%) & $\mathrm{l}_{0}$ & $l_{1}$ & $l_{2}$ & $l_{3}$ & $(*)$ & $1_{4}$ & $1_{5}$ & $l_{6}$ \\
\hline 1. Drainage & $\mathrm{d}_{0} / \mathrm{d}_{1}$ & $\mathrm{~d}_{2}$ & $\mathrm{~d}_{3}$ & $\mathrm{~d}_{4}$ & $(* *)$ & $(*)$ & $(*)$ & $(*)$ \\
\hline 2. Effective depth & $\mathrm{k}_{0}$ & $\mathrm{k}_{0}$ & $\mathrm{k}_{1}$ & $\mathrm{k}_{2}$ & $(*)$ & $\mathrm{k}_{3}$ & $(*)$ & $(*)$ \\
\hline 5. Erosion & $\mathrm{e}_{0}$ & $\mathrm{e}_{1}$ & $\mathrm{e}_{1}$ & $\mathrm{e}_{2}$ & $(*)$ & $\mathrm{e}_{3}$ & $\mathrm{e}_{4}$ & $(*)$ \\
\hline 6. Gravel/rock & $\mathrm{b}_{0}$ & $\mathrm{~b}_{0}$ & $\mathrm{~b}_{0}$ & $\mathrm{~b}_{1}$ & $b_{2}$ & $(*)$ & $(*)$ & $\mathrm{b}_{3}$ \\
\hline 7. Flood & $\mathrm{O}_{0}$ & $\mathrm{O}_{1}$ & $\mathrm{O}_{2}$ & $\mathrm{O}_{3}$ & $\mathrm{O}_{4}$ & $(*)$ & $(*)$ & $(*)$ \\
\hline
\end{tabular}

Source: Modified by Arsyad (2010); Hardjowigeno (2011); Widiatmaka (2015) 


\section{Description:}

$(*)$ : It can have any limiting properties of the lower classes

$(* *)$ : the ground surface is always inundated

1) Texture : $\mathrm{t} 1$ : fine; $\mathrm{t} 2$ : rather fine; $\mathrm{t} 3$ :medium; $\mathrm{t} 4$ : rather coarse; $\mathrm{t} 5$ :coarse;

2) Slope: I0: $(0-3 \%$; I1 $(3-8 \%)$; I2 $(8-15 \%)$; I3 (15- 30\%); I4 (30- 45\%); I5(45-65\%); I6 (> 65\%);

3)Drainage: D0 (good): D1 (rather good); D2 (rather bad); D3 (bad); D4 (very bad)

4)Effective soil depth: K0 (deep); K1 (moderately deep); K2 (shallow); K3 (very shallow);

5)State of Erosion: e0 (no erosion); e1 (light); e2 (moderate); e3 (heavy); e4 (very heavy).

6)Gravel/Stone: b0: nothing or little b 1 :medium; b 2 : many; b 3 :very much

7)Flooding O0: none; $\mathrm{O} 1$ :rarely; O2 : sometimes; O3 : Frequently; O4 : very frequently

\section{RESULTS AND DISCUSSION}

\section{Class of Land Use Capability Based on Intensive Observation in Upper Ciliwung Watershed}

Unit of land use for intensive observation of land capability class was formulated based on the overlapping result of soil maps, slope maps and land use of upper Ciliwung watershed. Unit of land use used for intensive observation was as many as 60 units of land use spread over seven (7) subwatersheds, namely sub-watershed of Cibalok, Cisuren, Ciliwung, Ciesek, Cisukabirus, Cisarua and Ciseseupan.
The unit of land use of which its land capability class was analyzed included the use of shrubland, open land, and dryland agriculture. The unit of land use is used as a recommendation for the use of agroforestry in upper Ciliwung watershed. The results of evaluation of land capability consisted of land capability of class II which covered an area of 329.7 ha $(23.92 \%)$, capability class III covering 464.8 ha $(33.72 \%)$ and capability class IV covering 584 ha $(42.36 \%)$. Units of land use and land capability class area in the upper Ciliwung watershed are presented in Table 2.

Table 2. Area of capability class of land use based on intensive observation in the upper Ciliwung watershed

\begin{tabular}{|c|c|c|c|}
\hline \multirow{2}{*}{$\begin{array}{l}\text { Land Capability } \\
\text { Class }\end{array}$} & \multirow{2}{*}{ Unit of Land Use } & \multicolumn{2}{|c|}{ Area } \\
\hline & & $\mathrm{Ha}$ & $\%$ \\
\hline \multirow[t]{2}{*}{ II } & SPL15 SB, SPL38 SB, SPL 6 SB & 329.7 & 23.92 \\
\hline & SPL5 LT, 4 PLK, 17LT, 13SB, 21LT, 41SB, & 464.8 & 33.72 \\
\hline \multirow[t]{2}{*}{ III } & $40 \mathrm{LT}, 21 \mathrm{LT}, 13 \mathrm{SB}, 38 \mathrm{LT}, 18 \mathrm{SB}, 6 \mathrm{SB}, 2$ & & \\
\hline & $6 \mathrm{SB}, 5 \mathrm{SB}, 15 \mathrm{SB}, 28 \mathrm{LT}, 38 \mathrm{LT}, 13 \mathrm{SB}, 41$ & 584 & 42.36 \\
\hline \multirow{3}{*}{ IV } & SB, $21 \mathrm{LT}, 18 \mathrm{SB}, 43 \mathrm{SB}, 4$ PLK, 10 PLK, 28 & & \\
\hline & $\begin{array}{l}\text { PLK, 7PLK, } 13 \text { SB, } 42 \text { LT, } 5 \text { LT, } 8 \text { PLK, } 2 \\
\text { PLK }\end{array}$ & & \\
\hline & Total & $1,378,505$ & 100 \\
\hline
\end{tabular}

Sources: Primary data from the analysis of spatial data, 2016

Description: $\mathrm{SPL}=$ Unit of land use; $\mathrm{SB}=$ Shrubs; $\mathrm{LT}=$ Open land; PLK = Dryland Agriculture 


\section{Analysis of Land Capability in Upper Ciliwung Watershed}

The evaluation results of land capability indicated that obstacle factors found in the upper Ciliwung watershed throughout the land capability class were erosion (mild, moderate and severe), slope (choppy, slightly undulating, hilly and steep) and drainage (bad). Results of the evaluation of the land capability class in the upper Ciliwung watershed are presented in (Table 3 and Figure 2).

Land of Class II L1, L2, e1 with limiting factors of slopes and erosion was spread on units of land 5,2,4,6,8 and 12 with limiting factors found in this class were still appropriate to its land use for agroforestry. Based on the obstacle factor which is still light, this land could be used in a sustainable manner by considering moderate conservation measures such as traditional terrace, patio benches, and vegetated channels. Concerning land management with limiting factors of slopes and erosion, it is required to apply soil conservation mechanically or using vegetation, in the long run with land use in the form of permanent vegetation and forests in the land with a limiting factor of slope and erosion which will reduce the destructive power of rainwater to the ground (Saida et al 2013).

One of obstacle factors of land capability class is the erosion which will result in a decrease in soil fertility, disrupt plant growth and reduce the productivity of crops. Therefore, erosion control to reduce the influence of factors causing erosion is required so that the erosion can be inhibited or reduced. Mulching can help maintaining soil particles and improving aggregation and soil aggregate stability; thus, it can reduce the impact of soil erosion (Ping et al 2012). Land of Class III L1, L2, e1 and $\mathrm{d} 1$ with limiting factors of slopes, erosion and drainage were found on land unit

of $13,5,7,6,15,28,17,21,4,38,15,42,18,20$ and 40. Land erodibility is one of soil properties that affects soil erosion, the greater the value of soil erodibility, the more sensitive the soil against erosion. Factor of management or treatment against the soil also affects the degree of soil erodibility (Nezami, 2013). Factor of soil erodibility on erosion repairment efforts can be done through the provision of organic materials to maintain the stability of soil aggregates. High organic matter content has high soil erodibility (Ping et at 2012). Considering the unit of land use with erosion as limiting factor, if this land is used for agriculture, soil conservation measures required are including making gulud porch, patio gulud ducts, planting in strips and mulching while channel manufacture is needed to repair a poor drainage. Pratiwi and Narendra (2012) suggested that the use of vertical mulching at the demonstration pot (demplot) of mahogany was able to increase plant growth by $66 \%$. Land of Class IV with limiting factors of erosion (light, medium and heavy), slope (choppy, slightly undulating, hilly and steep) and drainage (bad) was spread on the unit of land use of $6,17,10,20,5,38,15,28,18,13,43,21$, and 41. Obstacle and limitation on land of Class IV were bigger than those of Class III; thus, the selection of cultivated plants was very limited. Slope is threat factor leading to soil erosion. The steepness of the slope affects the size of the number of surface runoff. The greater the slope gradient, then the more the number of grains of soil that splashed down as an impact of raindrops (Harjianto et al 2016). 


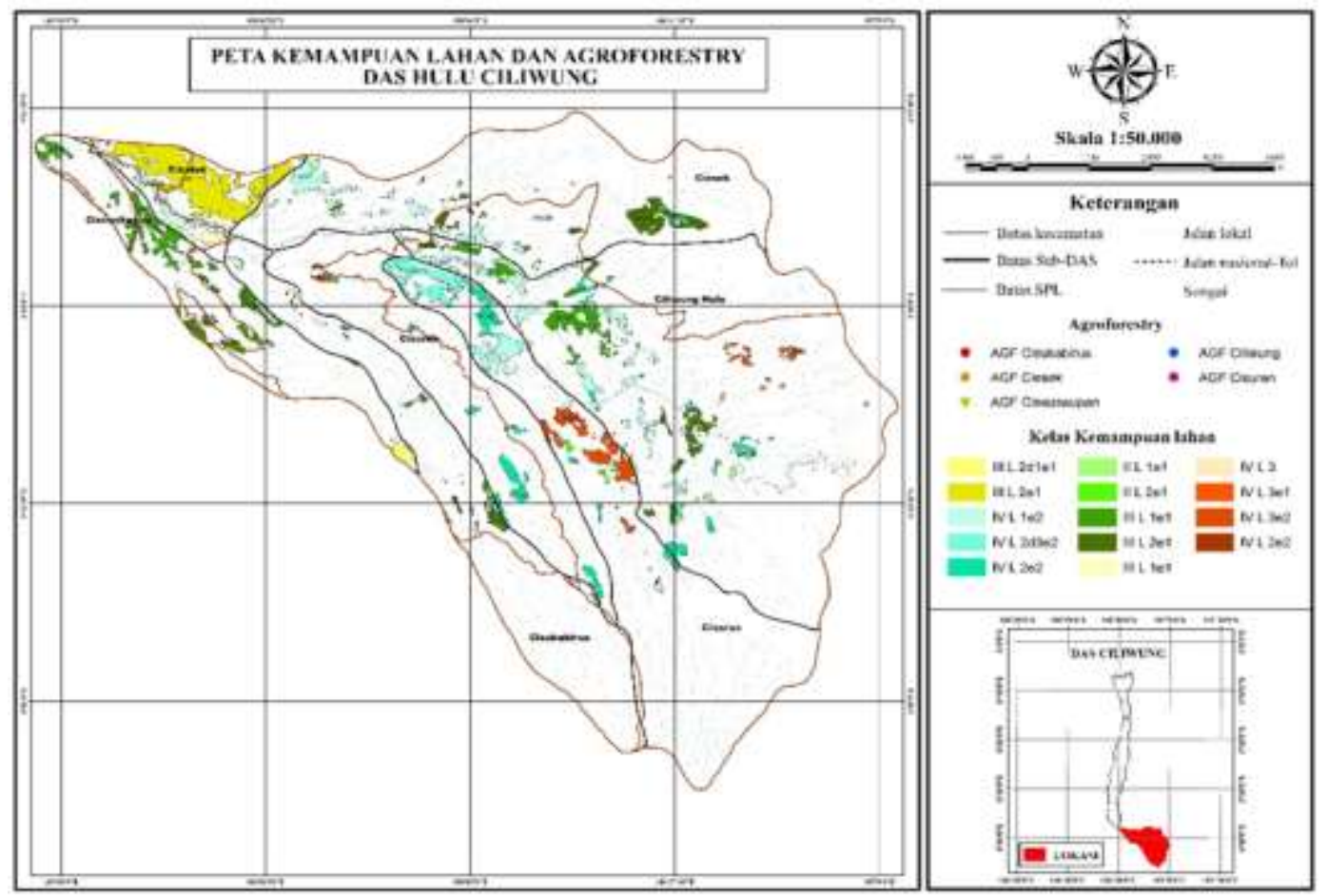

Figure 2. Map of land capability class in the Upper Ciliwung Watershed

Table 3. Land Capability Class in the Upper Ciliwung Watershed

\begin{tabular}{|c|c|c|c|}
\hline \multirow{2}{*}{$\begin{array}{l}\text { Land Capability } \\
\text { Class }\end{array}$} & \multirow{2}{*}{ Unit of Land Use } & \multicolumn{2}{|c|}{ Area } \\
\hline & & $\mathrm{Ha}$ & $\%$ \\
\hline II $\mathrm{L}_{1} \mathrm{e}_{1}$ & SPL5 LT, SPL2 PLK, SPL4 PLK, SPL6 SB, SPL8 LT & 259.7 & 18.8 \\
\hline II $\mathrm{L}_{2} \mathrm{e}_{1}$ & SPL12 PLK & 70.0 & 5.1 \\
\hline III L $\mathrm{L}_{1} \mathrm{e}_{1}$ & $\begin{array}{l}\text { SPL13 SB, SPL5 SB, SPL7 PLK, SPL6 SB, SPL15 SB, } \\
\text { SPL } 28 \text { LT }\end{array}$ & 95.1 & 6.9 \\
\hline III $\mathrm{L}_{2} \mathrm{e}_{1}$ & $\begin{array}{l}\text { SPL17 LT, SPL21 LT, SPL13 SB, SPL4 PLK, SPL38 } \\
\text { SB, SPL5 SB, SPL7 PLK, SPL15 SB, SPL6 SB }\end{array}$ & 329.4 & 23.9 \\
\hline III $\mathrm{L}_{1} \mathrm{e}_{1}$ & SPL42 LT, SPL28 LT & 17.8 & 1.3 \\
\hline III $\mathrm{L}_{2} \mathrm{~d}_{1} \mathrm{e}_{1}$ & SPL40 LT & 0.1 & 0.0 \\
\hline III L $\mathrm{L}_{2} \mathrm{e}_{1}$ & SPL21LT & 22.4 & 1.6 \\
\hline III $\mathrm{L}_{2} \mathrm{e}_{2}$ & $\begin{array}{c}\text { SPL41 LT, SPL18 SB, SPL13 SB, SPL4 PLK, SPL20 } \\
\text { SB, SPL6 SB, SPL15 SB, SPL21 LT, SPL10 PLK, } \\
\text { SPL18 SB, SPL13 SB, SPL5 LT, SPL2 PLK, SPL4 } \\
\text { PLK, SPL36 SB }\end{array}$ & 383.0 & 27.8 \\
\hline IV L $\mathrm{L}_{2} \mathrm{~d}_{3} \mathrm{e}_{2}$ & SPL6 SB & 58.3 & 4.2 \\
\hline IV $\mathrm{L}_{2} \mathrm{e}_{2}$ & $\begin{array}{l}\text { SPL17 LT, SPL10 PLK, SPL20 SB, SPL5 SB, SPL38 } \\
\text { LT, SPL6 SB, SPL15 SB, SPL28 PLK, SPL17 LT, } \\
\text { SPL18 SB, SPL13 SB }\end{array}$ & 82.1 & 6.0 \\
\hline IV $\mathrm{L}_{3}$ & SPL15 SB & 0.4 & 0.0 \\
\hline IV $\mathrm{L}_{3} \mathrm{e}_{1}$ & SPL6 SB, SPL38 SB, SPL43 SB, SPL21 LT, SPL41 SB & 36.4 & 2.6 \\
\hline IV $\mathrm{L}_{2} \mathrm{e}_{2}$ & SPL18 SB, SPL13 SB & 23.8 & 1.7 \\
\hline & Total & 8.505 & 100 \\
\hline
\end{tabular}

Sources: Primary data from the analysis of spatial data, 2016

Description: $\mathrm{SPL}=$ Unit of land use; $\mathrm{SB}=$ Shrubs; $\mathrm{LT}=$ Open land; PLK = Dryland Agriculture 


\section{Recommendation of Land Use in Upper Ciliwung Watershed}

Recommendation of land use in upper Ciliwung watershed was based on land capability analysis on shrub land, open land and dryland agriculture which spread over the unit of land use in the area of upper Ciliwung watershed which is generally recommended for agroforestry use. Land with Class II and III is recommended for agroforestry agrosilvopasture with gulud terrace, mulching and rorak (dead end trench). Constructing rorak is an alternative technique for soil and water conservation to reduce high level of erosion (Sumarno et al, 2011). Further application of mulching can affect the hydrological characteristics, i.e. decrease in discharge with peak between $64-69 \%$ and extension of the response time for 6 minutes on rainfall less than $21 \mathrm{~mm}$, and decrease in runoff and surface runoff coefficient between 14-75 and $17-74 \%$ ( Heryani et al, 2013). Land capability of Class IV is recommended for the development of plantation forests such as community forests and agroforestry Agrisilviculture accompanied by terracing individuals. Gulud terrace and rorak equipped with vertical mulching which can suppress the amount of suspended soil in water stream (Murtilaksono et al 2008). Recommendation of land use in the area of upper Ciliwung watershed is expected to reduce soil erosion that is the erosion must be smaller than the tolerated erosion. Land capability class and recommendation of land use as well as soil and water conservation techniques are presented in Table 4.

Table 4. Recommendations of agroforestry land use in Upper Ciliwung Watershed

\begin{tabular}{|c|c|c|}
\hline $\begin{array}{c}\text { Land Capability } \\
\text { Class }\end{array}$ & Unit of Land Use & Recommendations \\
\hline II L ${ }_{1} \mathrm{e}_{1}$ & $\begin{array}{l}\text { SPL5 LT, SPL2 PLK, SPL4 PLK, SPL6 SB, SPL8 } \\
\text { LT }\end{array}$ & Agrosilvopasture \\
\hline II L ${ }_{2} \mathrm{e}_{1}$ & SPL12 PLK & Agrosilvopasture \\
\hline III L $\mathrm{e}_{1}$ & $\begin{array}{l}\text { SPL13 SB, SPL5 SB, SPL7 PLK, SPL6 SB, } \\
\text { SPL15 SB, SPL } 28 \text { LT }\end{array}$ & Agrosilvopasture \\
\hline III L ${ }_{2} \mathrm{e}_{1}$ & $\begin{array}{l}\text { SPL17 LT, SPL21 LT, SPL13 SB, SPL4 PLK, } \\
\text { SPL38 SB, SPL5 SB, SPL7 PLK, SPL15 SB, } \\
\text { SPL6 SB }\end{array}$ & Agrosilvopasture \\
\hline III $\mathrm{L}_{1} \mathrm{e}_{1}$ & SPL42 LT, SPL28 LT & Agrosilvopasture \\
\hline III $L_{2} \mathrm{~d}_{1} \mathrm{e}_{1}$ & SPL40 LT & Agrosilvopasture \\
\hline III $\mathrm{L}_{2} \mathrm{e}_{1}$ & SPL21LT & Agrosilvopasture \\
\hline III L $\mathrm{L}_{2} \mathrm{e}_{2}$ & $\begin{array}{l}\text { SPL41 LT, SPL18 SB, SPL13 SB, SPL4 PLK, } \\
\text { SPL20 SB, SPL6 SB, SPL15 SB, SPL21 LT, } \\
\text { SPL10 PLK, SPL18 SB, SPL13 SB, SPL5 LT, } \\
\text { SPL2 PLK, SPL4 PLK, SPL36 SB }\end{array}$ & Agrosilvopasture \\
\hline IV L ${ }_{2} \mathrm{~d}_{3} \mathrm{e}_{2}$ & SPL6 SB & Agrisilviculture \\
\hline IV $\mathrm{L}_{2} \mathrm{e}_{2}$ & $\begin{array}{l}\text { SPL17 LT, SPL10 PLK, SPL20 SB, SPL5 SB, } \\
\text { SPL38 LT, SPL6 SB, SPL15 SB, SPL28 PLK, } \\
\text { SPL17 LT, SPL18 SB, SPL13 SB }\end{array}$ & Agrisilviculture \\
\hline $\mathrm{IV} \mathrm{L}_{3}$ & SPL15 SB & Agrisilviculture \\
\hline IV $L_{3} e_{1}$ & $\begin{array}{l}\text { SPL6 SB, SPL38 SB, SPL43 SB, SPL21 LT, } \\
\text { SPL41 SB }\end{array}$ & Agrisilviculture \\
\hline IV L $\mathrm{L}_{2} \mathrm{e}_{2}$ & SPL18 SB, SPL13 SB & \\
\hline
\end{tabular}

Sources: Primary data from the analysis of spatial data, 2016 Description: SPL = Unit of land use; $\mathrm{SB}=$ Shrubs; $\mathrm{LT}=$ Open land PL1K = Dryland Agriculture 


\section{CONCLUSION}

Results of the evaluation of land capability class in Upper Ciliwung Watershed consisted of land capability class II which covered an area of 329.7 ha $(23.92 \%)$, capability class III covering 464.8 ha $(33.72 \%)$ and capability class IV covering 584 ha $(42.36 \%)$. Land use was dominated by land capability class III with dominant obstacle factor of bumpy slope. Land capability analysis on shrubland, open land and dry land farming which spread over in unit of land use in the area of Upper Ciliwung Watershed is generally recommended for agroforestry land use. The use of agroforestry land in the area of Upper Ciliwung Watershed should be complied with the recommendation and is accompanied by the application of soil water conservation techniques. Soil and water conservation techniques such as gulud terracing, gulud terrace ducts, individual patio and mulching are needed to to minimize erosion.

\section{REFERENCES}

Arsyad, S. 2010. Konservasi tanah dan air. IPB Pr. Bogor.

Hardjowigeno S, Widiatmaka 2011 Evaluasi Lahan dan Perencanaan Tataguna Lahan Gadjah mada Univ. Press: Yogyakarta

Harjianto, M., Sinukaban, N., Tarigan, S.T. dan Haridjaja, O. 2016. Evaluasi kemampuan lahan untuk arahan penggunaan lahan di daerah aliran sungai lawo, Sulawesi selatan. Jurnal Penelitian Hutan 5 (1): 1-2.

Heryani N, Kartiwa B, Sugiarto Y dan handayani T. 2013. Pemberian mulsa dalam budidaya cabai rawit di lahan kering: dampaknya terhadap hasil tanaman dan aliran permukaan. J. Agron. Indonesia 41 (2): 150-152.

Marwah S. 2009. Optimalisasi pengelolaan sistem agroforestri untuk pembangunan berkelanjutan di DAS Konaweha,
Sulawesi Tenggara [disertasi]. Bogor (ID): Institut Pertanian Bogor.

Murtilaksono, K., Sutarta, H.H., Siregar, W., Darmosarkoro dan Hidayat Y. 2008. Penerapan teknik konservasi tanah dan air dalam penekanan aliran permukaan dan erosi di kebun kelapa sawit. Prosiding seminar dan kongres nasional MKTI VI, 17-18 Desember 2007, Cisarua Bogor: 165-168.

Nezami MT. 2013. Effect of land use types and slope on soil erodibility factor in alborz province, Iran. International research journal of applied and basic sciences 4(1) 2530.

Pawitan H. 2004. Perubahan penggunaan lahan dan pengaruhnya terhadap hidrologi daerah aliran sungai. Bogor (ID): laboratorium hidrometeorologi FMIPA

Ping LY, Sung CTB, Joo GK and Moradi A. 2012. Effects of four soil conservation methods on soil aggregate stability. Malaysian journal of soil science 16 ; 43-56.

Pratiwi dan Narendra BH. 2012. Pengaruh penerapan teknik konservasi tanah terhadap pertumbuhan pertanaman mahoni (Swietenia Macrophylla King) di hutan penelitian carita Jawa Barat. Jurnal penelitian hutan dan konservasi alam 9(2); 139-150.

Saida, Jusoff K, Islan M, Haris A and Nraeni. 2013. Evaluation of land capability for agriculture in the upstream of jeneberang watershed south sulawesi. American-eurasian journal of agricultural \& environmental sciences 13 (8); 10271033.

Sinukaban, N. 2007. Pengelolaan DAS. Materi kuliah pengelolaan das. Bogor: Sekolah Pascasarjana IPB.

Sitorus R.P.S.2010. Land capability classification for land evaluation: Review. Jurnal of agricultured land resource 4 (2): 69-78. 
Sumarno, Winarno J dan Prastomo I. 2011. Land management study based on the degree of erosion hazard and water and soil conservation pattern in ngadipiro, nguntoronadi, wonogiri. $\mathrm{J}$ ilmu tanah dan agroklimatologi 8 (1): 14-18.

Surni., Baja, S. dan Arsyad, U. 2015. Dinamika perubahan penggunaan lahan, penutupan lahan terhadap hilangnya biodiversitas di DAS Tallo, Sulawesi Selatan. Prosiding Seminar Nasional Masyarakat
Biodiversitas Indonesia. (10501051).

Widiatmaka, Ambarwulan W, Purwanto M Y J, Setiawan Y, Effendi H 2015 Land capability based environmental carrying capacity in Tuban, East Java. J. Man. Lingk. 222 247-259

Yalew D. and Yilak T. (2014). A GIS based land capability classification of guang watershed, highlands of ethiopia. Journal of environment and earth science, 4(22), 161-165. 